\title{
Rescaling drought mitigation in rural Sri Lanka
}

Dr. Emily Burchfield

Assistant Professor

Department of Environment and Society

Utah State University

Ph. 435.797.4089

Email.emily.burchfield@usu.edu

Dr. Nicholas E. Williams

Assistant Teaching Professor

Interdisciplinary and Global Studies Division

Worcester Polytechnic Institute

Email.newilliams@wpi.edu

Dr. Amanda Carrico

Assistant Professor

Department of Environmental Studies

University of Colorado, Boulder

Ph. 303.492.9162

Email: amanda.carrico@ucboulder.edu

\begin{abstract}
Smallholder farmers with limited governmental and institutional support often devise innovative strategies to mitigate the impacts of water stress on agricultural production. These drought mitigation strategies can be more culturally and ecologically suitable than top-down, "technocratic" strategies. Top-down drought mitigation approaches, however, often link farmers with significant infrastructures, financial resources, and specialized knowledge. Successful rescaling of localized mitigation practices can integrate the benefits of localized mitigation with resources available at larger scales. This paper describes the rescaling of a Sri Lankan drought mitigation practice known as bethma. We focus on the process of rescaling, specifically what is lost and gained when this local practice is implemented at a much larger scale. We identify factors driving participation in bethma and the impacts of this participation on farmer livelihoods. Results suggest that participation in bethma during water scarce seasons has significant positive impacts on agricultural yields, but that this participation is strongly influenced by a farmer's land ownership. Much of the success of bethma's implementation is due to the decentralized, flexible implementation at a regional scale. The loss of localized information, however, influences farmer participation in the practices and the distribution of the benefits associated with bethma.
\end{abstract}

\section{Key words}

Drought, mitigation, scale, agriculture, bethma, Sri Lanka

\section{Acknowledgements}

United States National Science Foundation Water, Sustainability, and Climate grant EAR1204685 funded this research. Dr. Burchfield thanks the American Institute for Sri Lankan studies for a Dissertation Travel Grant which funded travel to collect qualitative data. We thank the anonymous reviewers for helpful suggestions that improved the paper. 


\section{Rescaling drought mitigation in rural Sri Lanka}

\section{Introduction}

Smallholder farmers with limited governmental and institutional support often devise innovative strategies to mitigate the impacts of water stress on agricultural production (Eakin et al., 2013; Gandure, Walker, \& Botha, 2013). These drought mitigation strategies can be more culturally and ecologically suitable than top-down, "technocratic" strategies, allowing farmers to integrate their highly specialized knowledge of the local agro-ecological system in the design of the mitigation practice (Adger, Barnett, Brown, Marshall, \& O'Brien, 2013; Petheram, Zander, Campbell, High, \& Stacey, 2010). Top-down drought mitigation approaches, however, often link farmers with significant infrastructures, financial resources, and specialized knowledge (Wilhite, Svoboda, \& Hayes, 2007; Wilhite \& Vanyarkho, 2000). In many cases, the active, intentional involvement of the government can significantly boost farmers' capacity to mitigate drought, particularly through access to large water storage and diversion infrastructures (Moss \& Newig, 2010).

A growing body of research suggests that the rescaling of localized drought mitigation strategies to regional or even national scales can increase the capacity of agricultural systems to mitigate water stress (Berkes \& Jolly, 2002; Eakin et al., 2013; Jabeen, Johnson, \& Allen, 2010; Stringer et al., 2009; Valdivia et al., 2010). Successful rescaling can effectively integrate the benefits of localized mitigation with resources available at larger scales. To date, there are relatively few documented examples of initiatives to formalize and implement locally-developed adaptive agricultural strategies at larger scales (Agrawal \& Perrin, 2009; Nakashima, Galloway McLean, Thulstrup, Ramos-Castillo, \& Rubis, 2012; Nyong, Adesina, \& Elasha, 2007). Understanding this process and its impacts on farmer livelihoods is a central concern in smallholder agricultural systems in which farmers are most vulnerable to environmental change (Adger, Arnell, \& Tompkins, 2005; A Agrawal \& Perrin, 2009; Eakin et al., 2013; Stringer et al., 2009). This paper describes the rescaling of a Sri Lankan drought mitigation practice known as bethma. We focus on the process of rescaling, specifically what is lost and gained when this local practice is implemented at a much larger scale.

Over thousands of years, communities in rural Sri Lanka have developed systems to capture, store, and distribute wet season water for cultivation during a second, drier agricultural season (Bebermeier, Meister, Withanachchi, Middelhaufe, \& Schütt, 2017; Panabokke, Sakthivadivel, \& Weerasinghe, 2002). During particularly water-stressed dry seasons, farmers in these systems practice bethma, or "division." Bethma is a collective drought mitigation technique in which permanent field boundaries are temporarily abolished, the total command area irrigated by a reservoir is reduced, and the remaining land is redistributed amongst all farmers who cultivate in the total command area. This redistribution process is complex and varies from system to system, but in general, each family receives equal-sized parcels of land regardless of land ownership. This practice evolved from a land tenure system in which each household owned fields at the head, middle, and tail-end of a command area. This system was designed to mitigate inequalities in water access that often emerge between head-end fields near the mouth of a reservoir and those at the tail-end of the command area (Chambers, 1988; Chandrapala, 
Chanaka, De Silva, \& Jayalath, 2013; Moore, 1989). Under this land tenure system, all farmers in a command area cultivate only their head-end fields when practicing bethma. Decisions about the nature of land and water reallocation are negotiated collectively at the beginning of the season by farmers in the community (Thiruchelvam, 2010).

In the 1950s, the Sri Lankan government began the construction of a massive irrigation system that diverted the water of nation's largest river, the Mahaweli Ganga, through a system of large-scale, centrally managed reservoirs, hydropower plants, and canals. The government created the Mahaweli Authority of Sri Lanka (MASL) and charged the institution with the management of this irrigation network and the selection of "settler" families to be relocated from densely populated coastal regions to the MASL systems (Zubair, 2005). Settlers were given 2.5 acres of irrigated land on which they were encouraged to cultivate paddy (Azmi, 2007; Moore, 1989). Though many small-scale village-based irrigation systems still operate in the dry zone today, ${ }^{1}$ the MASL irrigation infrastructure ${ }^{2}$ dominates the region, with over 100,000 hectares of irrigable land and over 10,000 kilometers of canals (Figure 1). An estimated 878,000 people, or 4.5 percent of the Sri Lankan population, live within these systems (MASL/UMWRDP, 2013). Farmers in these systems produce 800,000 metric tons of paddy annually and hydropower plants at these systems' main reservoirs generate approximately 40 percent of the nation's electricity demand (Manthrithilake \& Liyanagama, 2012).

Figure 1: Agroecology and irrigation jurisdiction in rural Sri Lanka

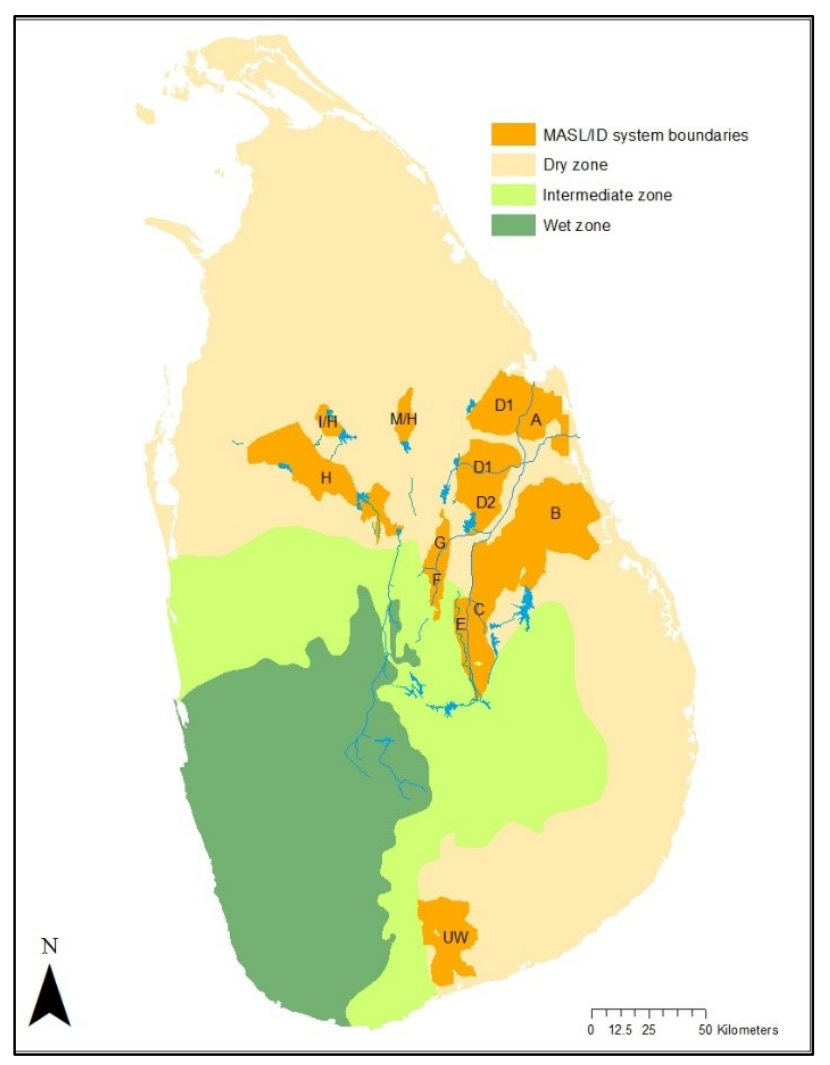

\footnotetext{
1 The Sri Lankan government lists over 11,250 locally managed systems (Imbulana, Wijesekera, \& Neupane, 2006).

${ }^{2}$ Large-scale irrigation systems with command areas greater than 400 ha.
} 
Caption 1: MASL and ID irrigation system boundaries are shown in orange, each labeled with its lettered name. The main canals, rivers, and reservoirs connecting these systems to the wet zone are shown in blue.

In recent years, increased prevalence of drought has pushed Sri Lankan water management institutions to implement bethma in these large-scale systems. The sheer scale of the MASL systems renders it nearly impossible for farmers to manage bethma as it was originally managed in village-based irrigation systems. The MASL systems are heavily engineered and centrally managed, with national and system-level water managers making key decisions about water allocations through the irrigation network. Intra-system water allocations are managed largely by system-level managers and farmer organizations, who meet regularly to ensure fair allocation of field-scale irrigation water. Unlike the village-based systems in which farmers cultivated three fields at the head, middle, and tail-end of the command area, MASL farmers cultivate only one field.

We are interested in how the rescaling of bethma affects farmer livelihoods during periods of drought. We focus on the practice of bethma during a severe 2014 drought that affected the livelihoods of over one million Sri Lankans (World Food Programme, 2014). We are particularly interested in the factors that drive individual participation in and access to bethma, the scales at which key decisions are made, and the overall effectiveness of participation in bethma on farmer livelihoods in the MASL systems. In what follows, we describe the process of bethma's regional implementation, its impact on farmer livelihoods, and variations in farmer participation in the practice.

\section{Methods}

In August 2015, we visited eight MASL irrigation communities (Figure 2) and conducted semi-structured interviews with 45 farmers across these systems. The majority of these farmers owned small agricultural parcels, typically less than 2.5 acres. We also interviewed 23 local, regional, and national water management officials including agricultural extension officers, water controllers, farmer organization leaders, irrigation engineers, system managers, and national officials. In each interview, we asked interviewees to describe how bethma is typically implemented in their communities, who participates, and the overall effectiveness of the practice. 
Figure 2: Map of survey and interview sites

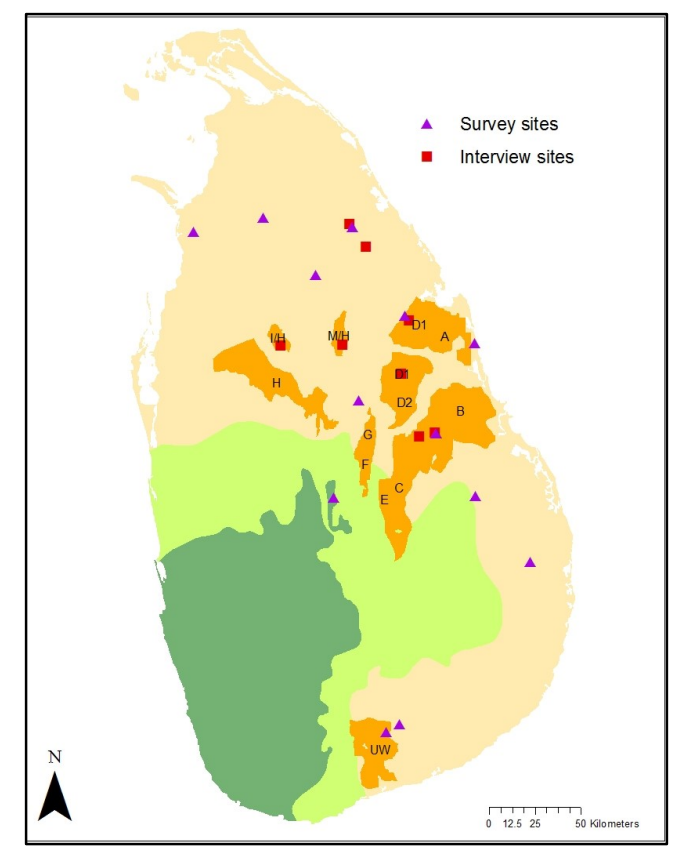

Caption 2: The eight interview sites are represented with red squares and the household survey communities represented with purple triangles. Interviews were conducted during the summer of 2015 and the survey data was collected following the dry season drought in 2014.

In addition to the interview data, we analyzed data from a 2015 household survey conducted with farmers $(n=607)$ from thirteen communities in Sri Lanka's dry zone (Figure 2). Communities were selected through a stratified random sampling procedure to ensure geographic dispersion throughout the region, and to select communities within both MASL and village-based irrigation systems. Within villages, $30-80$ households (weighted according to the size of the population) were randomly selected from a sampling frame that included all rice farming households living within the village. Trained local interviewers approached each selected household and asked if they would participate in a survey about agriculture and drought. Interviewers asked to speak to the person in the household who makes the majority of farming decisions. Most often this was the male head of household. Some information about the household was also collected from the head female (typically the farmer's spouse). The survey instrument collected information regarding a range of topics including: demographics, household economics, agricultural activities, community participation, and psychosocial data. We are interested in the scaling up of bethma in MASL systems, and only analyzed survey data from respondents living in the six major irrigation communities included in our survey. Of the 285 selfidentified 'head farmers' residing in the six major irrigation system communities, only 21 were female. Additionally, despite random sampling of households within communities, all respondents 
in each community were members of the same ethnic group ${ }^{3}$, reflecting the ethnic homogeneity of many dry zone communities.

To identify the factors that drove variations in bethma participation in these three communities, we fit a Bayesian logistic model to the survey data where a farmer's probability of participating in bethma is modeled as $\operatorname{Pr}\left(y_{i}=1\right)=\operatorname{logit}^{-1}\left(\beta_{i} X\right)$. The respondent-level design matrix $X$ includes a set of indicators for key variables identified through interviews as potentially influential in farmers' decisions to engage in bethma. Because we have minimal prior knowledge about the effects of our variables on participation in bethma, we followed (Gelman, Jakulin, Grazia, Su, \& Su, 2008)) and set weakly informative Cauchy priors on coefficients with center 0 and scale 2.5. We rescaled non-binary variables to have a mean of zero and a standard deviation of 0.5 and left binary covariates unscaled because their coefficients can already be interpreted directly (Gelman, 2008).

\section{Results}

Unlike the historical implementation of bethma, which was managed by farmers living in a single village, the regional MASL implementation of bethma takes place across several scales. Though national and regional water managers determine the reductions in cultivated extent in each system, system-level managers and the farmers themselves determine which fields are cultivated and how land is reallocated. This flexible, decentralized approach allows bethma to reflect the specific socio-environmental characteristics of each system (e.g. topography, canal infrastructure, social groupings along canals, etc.) and appears to significantly increase the effectiveness of its implementation in large-scale systems. In what follows, we describe this flexible approach and discuss the factors driving individual participation in and access to bethma. We first present an overview of the institutionalization of bethma in major irrigation systems as described in interviews with farmers, water managers, and local officials in eight communities across the dry zone. We then analyze this data to identify the factors that explain individual-level variations in participation in bethma during the 2014 drought. Finally, we model data collected from a 2014 household survey to identify the factor driving participation in bethma and that ultimately affect farmer yields

\subsection{Institutionalization of bethma}

National officials determine seasonal water allocations and cultivated extents in each MASL system based on reservoir levels and expected rainfall. During periods of drought, these officials reduce seasonal inflows to certain systems and recommend percent reductions in cultivated extent. System-level officials identify the specific subset of the command area to be cultivated. Our interviews identified several approaches frequently used by system-level officials to select this subset of land. The first approach resembles bethma as traditionally practiced in village-based irrigation systems in which farmers owning head-end fields near the reservoir divide and share their land with tail-end farmers. This approach minimizes conveyance loss in waterstressed seasons by reducing the distance water has to travel to reach farmers' fields. In the

\footnotetext{
${ }^{3}$ Bethma often takes place across multiple communities that are home to diverse ethnic groups. Our survey data only captures intra-community dynamics.
} 
large command areas of the MASL systems, however, tail-end farmers can incur significant travel costs when traveling from their homes to their temporary head-end plots. In one interview community, the cost of traveling over 40 kilometers a day forced tail-end farmers to sell their headend plots back to the original owners at very low prices. These farmers sent a formal complaint to system-level officials, who responded by implementing an alternative approach in which farmers cultivated the head-end of each canal branching off of the main canals in the system, rather than forcing all farmers to move to the head-end of the entire command area. This approach reduces the total distance traveled by tail-end farmers, but decreases water use efficiency by increasing the total distance water travels along the main canal. In addition to these two approaches to land redistribution, local managers also mentioned a land reallocation approach in which each farmer cultivates a subset of their original plot. This approach is typically only employed in very small command areas. Other systems transfer all available water to a single main canal. This approach is useful in systems with significant elevation differences between the main canals.

Once the subset of the command area is identified, farmer organizations (FO) manage the division and reallocation of parcels of land. Sri Lankan farmer organizations are heavily involved in field-scale water management. FO membership is common, as government fertilizer subsidies and mother services are often distributed through FOs. These FOs determine how farmers will move within the designated subset of land. Typically, all farmers are given equal sized plots of land from the pre-existing command area regardless of prior land holdings. The actual plot size depends on the size of the reduced command area and the number of water users. In most systems, if land will be subdivided into plots smaller than half an acre, farmers abandon bethma because the potential gains from cultivation are too small. Any land allocation conflicts that cannot be managed by the local FO are managed by system-level water management officials.

\subsection{Individual participation in bethma}

Our interviews suggest that the most important determinants of bethma participation are agrowell ownership, plot size, and relative position in the command area. Agrowells allow farmers to irrigate fields without relying on surface water allocations from the main system reservoir. ${ }^{4}$ Water pumped from an agrowell is generally insufficient to grow paddy, so these farmers typically cultivate other field crops (OFCs) such as soy, chilies, and onions. These crops require less water than paddy, but lack a stable market in Sri Lanka, require more labor, and are highly perishable (Burchfield \& Gilligan, 2016a, 2016b; Chandrasiri \& Baminiarachchi, 2015). Despite these risks, many farmers we interviewed opted out of bethma to cultivate larger areas with OFCs during the 2014 drought. Another significant constraint to participation in bethma is a farmer's field size. When farmers were originally resettled into MASL systems, each farming family received 2.5 acres of irrigated land. Today, second and third generation settlers cultivate highly fragmented versions of the original 2.5 acres (Azmi, 2007; Jinapala, De Silva, Aheeyar, Needs, \& Management, 2010). In highly fragmented areas, this is often a serious barrier that prevents many farmers from participating in bethma. Farmers cultivating plots too small to subdivide for bethma (less than half an acre) are likely to abandon bethma and seek employment elsewhere

\footnotetext{
${ }^{4}$ It should be noted that many agrowells are recharged by seasonal surface water flows, so in extremely water scarce seasons, many of these wells go dry (Kikuchi, Barker, Weligamage, \& Samad, 2002; Villholth \& Rajasooriyar, 2009).
} 
during the water-stressed season. Finally, under most bethma configurations, tail-end farmers must move up to the head-end of the system to cultivate portions of head-end fields. Many tailend farmers reported that they were unable to bear the expense associated with traveling to the head-end of the system throughout the season and sought work elsewhere.

Based on the predictors of participation in bethma identified in the interviews, we fit the following model to the survey data to test the importance of these predictors across communities:

$$
\operatorname{Pr}\left(y_{i}=1\right)=\operatorname{logit}^{-1}\left(\alpha+\beta_{A W} A W_{i}+\beta_{F O} F O_{i}+\beta_{A C R E} A C R E_{i}+\beta_{T E} T E_{i}+\beta_{S E S} S E S_{i}\right)
$$

where $y_{i}$ is the probability of a farmer participating in bethma, AW is a binary indicator of agrowell ownership, FO flags farmer participation in the local FO, ACRE is the total acres cultivated by the farmer, TE is a flag indicating whether or not the majority of the farmers' fields are located at the tail-end of their field canal, and SES is an index of socio-economic status we developed through principle component analysis of various household material assets but not including land (Vyas \& Kumaranayake, 2006). Survey questions associated with each variable are presented in Table 1.

The results of our analysis are presented in Table $2 .^{5}$ The table shows the mean value for each coefficient as well as the 97.5 percent confidence intervals. Estimated effects whose $97.5 \%$ confidence intervals do not intersect zero are of particular interest. Despite the importance of farmer organizations in the local implementation of bethma, our model does not identify farmer organization membership as a significant predictor of individual participation in bethma. We also find no significant effect of relative position of a farmer's field within the command area or of agrowell ownership. Our results do suggest, however, that a one acre increase in land held by a farmer increases their probability of participation in bethma by 25 percent. We believe this finding is best explained by the land fragmentation that occurs in the region. Although landholdings in the MASL systems are formally required to be passed to a single heir, family members often informally divide inherited plots. When land use is further restricted under bethma, the farmers cultivating these fragmented plots are less likely to engage in bethma. The results also suggest that a one standard deviation increase in a farmer's SES decreases their probability of participation in bethma by 17.5 percent. The strong negative effect of a higher SES on participation in bethma may reflect the fact that wealthier households tend to engage in non-agricultural livelihood activities during periods of drought.

Table 1: Survey questions

\begin{tabular}{ll}
\hline Survey Question & Variable Name \\
\hline Who owns the agrowell used by the household? & AW \\
Did you practice bethma during the 2014 dry season? & BETHMA \\
Are you a member of the farmer organization? & FO \\
How many acres of paddy/lowland are held by the household? & ACRE \\
Location of field on field canal (head, middle, tail)? & TE \\
Index composed using reported list of household assets & SES
\end{tabular}

\footnotetext{
${ }^{5}$ We report beta coefficients divided by four to make results more easily interpretable. This new value is indicative of the difference in probability of participation in bethma associated with a one unit change of the corresponding covariate (Gelman \& Hill, 2007).
} 
Highest level of education completed?

ELEM, MIDDLE, HIGH, POSTHIGH

Table 2: Factors driving individual participation in bethma

\begin{tabular}{l|l|l|l|l|l}
\hline Parameter & Mean & $\begin{array}{l}\text { Standard } \\
\text { deviation }\end{array}$ & $\mathbf{2 . 5} \%$ & $\mathbf{5 0} \%$ & $\mathbf{9 7 . 5 \%}$ \\
\hline AW & 0.075 & 0.2 & -0.325 & 0.075 & 0.5 \\
FO & 0.025 & 0.2 & -0.325 & 0.025 & 0.425 \\
OFC & 0.0 & 0.125 & -0.25 & 0.0 & 0.275 \\
ACRE & 0.25 & 0,125 & 0.05 & 0.25 & 0.5 \\
TE & -0.1 & 0.125 & -0.35 & -0.1 & 0.125 \\
SES & -0.175 & 0.1 & -0.4 & -0.175 & 0.025
\end{tabular}

\subsection{Livelihoods impacts of bethma}

To determine whether participation in bethma has measurable impacts on farmer livelihoods, we constructed a linear Bayesian model to estimate the effect of bethma participation on seasonal rice yield:

$$
\begin{aligned}
\log (\text { bushelsperacre })= & \alpha+\beta_{A W} A W_{i}+\beta_{A G E} A G E+\beta_{\text {BETHMA }} \text { BETHMA }+\beta_{F O} F_{i}+\beta_{A C R E} A C R E_{i} \\
& +\beta_{T E} E_{i}+\beta_{S E S} S E S_{i}+\beta_{\text {EDUCATION }} \text { EDUCATION }
\end{aligned}
$$

We include the same predictors as in the bethma participation regression, but add controls for farmer experience (AGE and EDUCATION) and a variable indicating whether or not the farmer engaged in bethma during the 2014 drought (BETHMA).

Table 3: The effect of participation in bethma on log rice yields

\begin{tabular}{llllll}
\hline Parameter & Mean & $\begin{array}{l}\text { Standard } \\
\text { deviation }\end{array}$ & $\mathbf{2 . 5 \%}$ & $\mathbf{5 0 \%}$ & $\mathbf{9 7 . 5 \%}$ \\
\hline AW & 1.3 & 0.9 & -0.5 & 1.3 & 3.2 \\
BETHMA & 1.9 & 0.5 & 1.0 & 1.9 & 2.8 \\
FO & 1.5 & 0.9 & -0.2 & 1.5 & 3.3 \\
ACRE & 0.6 & 0.5 & -0.4 & 0.6 & 1.5 \\
TE & 0.7 & 0.5 & -0.3 & 0.7 & 1.7 \\
SES & 0.2 & 0.5 & -0.7 & 0.2 & 1.1 \\
ELEMENTARY & 0.1 & 1.3 & -2.4 & 0.0 & 2.7 \\
MIDDLE & -0.2 & 1.2 & -2.5 & -0.2 & 2.3 \\
HIGH & 0.5 & 1.3 & -1.9 & 0.0 & 3.1 \\
POSTHIGH & -0.2 & 1.3 & -2.8 & -0.2 & 2.5
\end{tabular}

Our analysis of yield during the 2014 drought shows that, controlling for alternative water sources (AW), membership in the local farmer organization (FO), land holdings (PADDY), socioeconomic status (SES), and farmer experience, a farmer's participation in bethma had a strongly positive impact on paddy yield during the 2014 drought. Our findings also indicate that ownership 
of an agrowell significantly boosts yields during periods of water scarcity. The positive effect of farmer organization membership on yield likely reflects increased access to extension efforts, agricultural inputs, and influence over the implementation of bethma.

\section{Discussion}

Agricultural water scarcity is a serious problem in rural Sri Lanka. Future changes in climate will alter the timing and duration of seasonal monsoons, further straining agricultural production on the island (De Silva et al., 2007). In addition, the Sri Lankan population is expected to increase by 15 percent in the next 30 years, further straining limited water supplies and fragmenting agricultural land (Imbulana, Wijesekera, \& Neupane, 2006). In response to these stressors, Sri Lankan water managers have rescaled and institutionalized a locally-developed drought mitigation technique known as bethma at the regional and national scales. Scholars have warned that the institutionalization of bethma by the MASL will create a loss of "village identity and exclusivity as a result of state interventions" (Abeyratne, Perera, \& others, 1986, p. 118). Others have argued that government interest in bethma has ensured the survival of the practice and has bolstered farmer livelihoods during water-stressed seasons (Thiruchelvam, 2010). Our analyses suggest that the rescaling of this drought mitigation practice has had positive effects on farmer livelihoods during periods of water scarcity. This rescaling of bethma does increase government oversight of local water allocations, but many farmers expressed a willingness to lose local oversight in exchange for access to the significant irrigation infrastructures maintained by the Sri Lankan government.

Much of bethma's success is due to its decentralized implementation. Though key diversion decisions are made by national water managers based on seasonal water availability and projected water demands, system- and field-level responses to these decisions are highly flexible. System-level managers and farmers have legitimate decision-making procedures that allow them to integrate their experiential, institutional, and contextual knowledge. This flexibility rescales key decisions to the most appropriate scale of concern (Gibson, Ostrom, \& Ahn, 2000; Risbey, Kandlikar, Dowlatabadi, \& Graetz, 1999; Termeer, Dewulf, \& Lieshout, 2010). For example, system-level managers can determine specific land and water reallocations based on the specific social and environmental layout of their irrigation system. Farmers can negotiate field-level reallocations based on their preferences and social networks. This nested flexibility integrates national expertise (network infrastructure, storage capacity, water demands, seasonal water availability) with local expertise (field suitability, local irrigation network, farmer preferences). This decentralization of knowledge and key decisions helps to limit conflicts between managers and water users (Holling 1986, 1995, Clark 1987, Cash et al., 2006, Wolf 2007). It also facilitates the integration of highly diverse and specific information relative to each irrigation system, canal, and field (Agrawal \& Perrin, 2009). The flexible implementation of bethma allows each system-level implementation of bethma to reflect decision makers' consideration of different objectives, scalar priorities, and system constraints.

Despite the successful decentralization of bethma and the measurable impact of participation in bethma on farmers yields, we also find significant intra-community variation in participation in bethma. Our interviews and survey analyses suggest that much of this variation is associated with the size of a farmer's landholdings. In the village-based irrigation systems in 
which bethma emerged, the community of farmers collaborates to reallocate land and water. Members of the community are often neighbors and/or members of the same family. These communities possess informal knowledge of land ownership, land fragmentation, and system characteristics. In MASL systems, farmers cultivating on informally fragmented fields are often left out of the bethma process. This suggests that future attempts to implement bethma should focus on equitable participation in and distribution of the benefits associated with bethma.

\section{Conclusion}

Our analysis details the rescaling of a local drought mitigation practice to a regional scale. Our results suggest that farmers who participate in this rescaled mitigation practice have higher yields than those who do not; however, we also find significant variations in access to this practice across farmers. Though the benefits of bethma are not distributed equally throughout communities, the practice appears to be a powerful tool for mitigating changes in water availability in the Sri Lankan dry zone. The successful rescaling of bethma is due largely to the flexibility and decentralization of its implementation. Farmers and system-level managers agree upon the most appropriate implementation of bethma for their locality, avoiding key geographical, social, and environmental pitfalls that may prevent the successful execution of this mitigation approach. At an even smaller scale, groups of farmers manage the process of land redistribution among themselves, allowing the integration of local knowledge of specific fields and canals in the irrigation network. Intervention from higher levels is only necessary when conflicts emerge.

Resource managers and decision makers in other regions of the world interested in promoting local mitigation practices regionally and nationally can learn two important lessons from the Sri Lankan institutionalization of bethma. First, the successful national promotion of local mitigation practices requires flexible and decentralized implementation. In the case of Sri Lanka, though national water managers determine the reduction in water flows and cultivated extent for a water scarce season, local managers are responsible for determining which subset of the command area will be cultivated. This allows local knowledge of social and environmental constraints to be integrated into bethma's design and implementation. Second, policy makers

must allow high levels of cross-scale communication. Local resource users must be able to communicate with local and national officials. Similarly, the expectations of national policy makers must be clear to local communities. 


\section{References}

Abeyratne, S., Perera, J. (1986). Change and continuity in village irrigation system: a case study in the Moneragala district, Sri Lanka. Retrieved from http://harti.nsf.ac.lk/handle/1/2267

Adger, W. N., Arnell, N. W., \& Tompkins, E. L. (2005). Successful adaptation to climate change across scales. Global Environmental Change, 15(2), 77-86. https://doi.org/10.1016/j.gloenvcha.2004.12.005

Adger, W. N., Barnett, J., Brown, K., Marshall, N., \& O’Brien, K. (2013). Cultural dimensions of climate change impacts and adaptation. Nature Climate Change, 3(2), 112-117. https://doi.org/10.1038/nclimate1666

Agrawal, A., \& Perrin, N. (2009). Climate Adaptation, Local Institutions and Rural Livelihoods. In W. N. Adger, L. I, \& K. O'Brien (Eds.), Adapting to Climate Change: Thresholds, Values, Governance (pp. 350-67). School of Natural Resources and Environment, University of Michigan. International Forestry Resources and Institutions Program, IFRI. Working Paper, W081-6.

Azmi, F. (2007). Changing livelihoods among the second and third generations of settlers in System $\mathrm{H}$ of the Accelerated Mahaweli Development Project (AMDP) in Sri Lanka. Norsk Geografisk Tidsskrift - Norwegian Journal of Geography, 61(1), 1-12. https://doi.org/10.1080/00291950601173903

Bebermeier, W., Meister, J., Withanachchi, C. R., Middelhaufe, I., \& Schütt, B. (2017). Tank Cascade Systems as a Sustainable Measure of Watershed Management in South Asia. Water, 9(3), 231. https://doi.org/10.3390/w9030231

Berkes, F., \& Jolly, D. (2002). Adapting to climate change: Social-ecological resilience in a Canadian western arctic community. Ecology and Society, 5(2), 8.

Burchfield, E., \& Gilligan, J. (2016a). Agricultural adaptation to drought in the Sri Lankan dry zone. Applied Geography, 77, 92-100. https://doi.org/10.1016/j.apgeog.2016.10.003

Burchfield, E. K., \& Gilligan, J. M. (2016b). Dynamics of individual and collective agricultural adaptation to water scarcity. In Winter Simulation Conference (WSC), 2016 (pp. 16781689). IEEE. Retrieved from http://ieeexplore.ieee.org/abstract/document/7822216/

Chambers, R. (1988). Managing canal irrigation: Practical analysis from South Asia. Cambridge, UK: Cambridge University Press.

Chandrapala, A. G., Chanaka, L. K., De Silva, S. H. S. A., \& Jayalath, H. A. P. (2013). Irrigation efficiency and water quality of Maduru Oya irrigation scheme. Annals of Sri Lanka Department of Agriculture, 15, 25-36.

Chandrasiri, J. K. M. D., \& Baminiarachchi, B. A. D. S. (2015). Reasons for low adoption of selected OFC and vegetable varieties released by the Department of Agriculture (No. 182). Reasons for low adoption of selected OFC and vegetable varieties released by the Department of Agriculture. Retrieved from http://www.harti.gov.Ik/images/download/reasearch_report/2016/182.pdf

Dharmasiri, L. M. (2008). Crop diversification for sustainable agriculture: A case study from the Mahaweli Development Programme of Sri Lanka. Sri Lanka Journal of Agrarian Studies, 12(1).

De Silva, C. S., Weatherhead, E. K., Knox, J. W., \& Rodriguez-Diaz, J. A. (2007). Predicting the impacts of climate change-A case study of paddy irrigation water requirements in Sri Lanka. Agricultural water management, 93(1), 19-29.

Eakin, H., Tucker, C. M., Castellanos, E., Diaz-Porras, R., Barrera, J. F., \& Morales, H. (2013). Adaptation in a multi-stressor environment: perceptions and responses to climatic and economic risks by coffee growers in Mesoamerica. Environment, Development and Sustainability, 16(1), 123-139. https://doi.org/10.1007/s10668-013-9466-9 
Gandure, S., Walker, S., \& Botha, J. J. (2013). Farmers' perceptions of adaptation to climate change and water stress in a South African rural community. Environmental Development, 5, 39-53. https://doi.org/10.1016/j.envdev.2012.11.004

Gelman, A. (2008). Scaling regression inputs by dividing by two standard deviations. Statistics in Medicine, 27, 2865-2873.

Gelman, A., \& Hill, J. (2007). Data analysis using regression and multilevel/hierarchical models. Cambridge University Press.

Gelman, A., Jakulin, A., Grazia, M., Su, P., \& Su, Y. (2008). A weakly informative default prior distribution for logistic and other regression models. The Annals of Applied Statistics, 2(4), 1360-1383.

Gibson, C. C., Ostrom, E., \& Ahn, T.-K. (2000). The concept of scale and the human dimensions of global change: a survey. Ecological Economics, 32(2), 217-239.

Imbulana, K. A. U. S., Wijesekera, N. T. S., \& Neupane, B. R. (2006). Sri Lanka National Water Development Report. Government of Sri Lanka.

Jabeen, H., Johnson, C., \& Allen, A. (2010). Built-in resilience: learning from grassroots coping strategies for climate variability. Environment and Urbanization, 22(2), 415-431. https://doi.org/10.1177/0956247810379937

Jinapala, K., De Silva, S., Aheeyar, M. M. M., Needs, D., \& Management, W. (2010). Volume 3: Policies, Institutions and Data Needs for Water Management. In National Conference on Water, Food Security and Climate Change in Sri Lanka (Vol. 3). Colombo, Sri Lanka: International Water Management Institute.

Kikuchi, M., Barker, R., Weligamage, P., \& Samad, M. (2002). Irrigation sector in Sri Lanka: Recent investment trends and the development path ahead (Vol. 62). IWMI.

Manthrithilake, H., \& Liyanagama, B. (2012). Simulation model for participatory decision making: water allocation policy implementation in Sri Lanka. Water International, (September), 37-41.

Moore, M. (1989). The fruits and fallacies of neoliberalism: The case of irrigation policy. World Development, 17(11), 1733-1750.

Moore, M. (1989). The ideological history of the Sri Lankan "peasantry." Modern Asian Studies, 23(1), 179-207.

Moss, T., \& Newig, J. (2010). Multilevel Water Governance and Problems of Scale: Setting the Stage for a Broader Debate. Environmental Management, 46(1), 1-6. https://doi.org/10.1007/s00267-010-9531-1

Nakashima, D. J., McLean, K. G., Thulstrup, H. D., Castillo, A. R., \& Rubis, J. T. (2012). Weathering uncertainty: traditional knowledge for climate change assessment and adaptation. Paris and Darwin: UNESCO and UNU.

Nyong, A., Adesina, F., \& Osman Elasha, B. (2007). The value of indigenous knowledge in climate change mitigation and adaptation strategies in the African Sahel. Mitigation and Adaptation Strategies for Global Change, 12(5), 787-797. https://doi.org/10.1007/s11027-007-9099-0

Panabokke, C. R., Sakthivadivel, R., \& Weerasinghe, A. D. (2002). Small tanks in Sri Lanka: evolution, present status, and issues. Colombo: International Water Management Institute.

Petheram, L., Zander, K. K., Campbell, B. M., High, C., \& Stacey, N. (2010). 'Strange changes': Indigenous perspectives of climate change and adaptation in NE Arnhem Land (Australia). Global Environmental Change, 20(4), 681-692. https://doi.org/10.1016/j.gloenvcha.2010.05.002

Risbey, J., Kandlikar, M., Dowlatabadi, H., \& Graetz, D. (1999). Scale, context, and decision making in agricultural adaptation to climate variability and change. Mitigation and Adaptation Strategies for Global Change, 4(2), 137-165. 
Stringer, L. C., Dyer, J. C., Reed, M. S., Dougill, A. J., Twyman, C., \& Mkwambisi, D. (2009). Adaptations to climate change, drought and desertification: local insights to enhance policy in southern Africa. Environmental Science \& Policy, 12(7), 748-765. https://doi.org/10.1016/j.envsci.2009.04.002

Termeer, C. J., Dewulf, A., \& Lieshout, M. van. (2010). Disentangling scale approaches in governance research: comparing monocentric, multilevel, and adaptive governance. Retrieved from http://repository.ubn.ru.nl/handle/2066/151894

Thiruchelvam, S. (2010). Agricultural production efficiency of Bethma cultivation in Mahaweli System H. Sri Lankan Journal of Agricultural Economics, 7. Retrieved from http://sjae.sljol.info/articles/10.4038/sjae.v7i0.1820/

Valdivia, C., Seth, A., Gilles, J. L., García, M., Jiménez, E., Cusicanqui, J., ... Yucra, E. (2010). Adapting to Climate Change in Andean Ecosystems: Landscapes, Capitals, and Perceptions Shaping Rural Livelihood Strategies and Linking Knowledge Systems. Annals of the Association of American Geographers, 100(4), 818-834. https://doi.org/10.1080/00045608.2010.500198

Villholth, K. G., \& Rajasooriyar, L. D. (2009). Groundwater resources and management challenges in Sri Lanka - an overview. Water Resources Management, 24(8), 14891513. https://doi.org/10.1007/s11269-009-9510-6

Vyas, S., \& Kumaranayake, L. (2006). Constructing socio-economic status indices: how to use principal components analysis. Health Policy and Planning, 21(6), 459-468. https://doi.org/10.1093/heapol/czl029

Wilhite, D. A., Svoboda, M. D., \& Hayes, M. J. (2007). Understanding the complex impacts of drought: A key to enhancing drought mitigation and preparedness. Water Resources Management, 21(5), 763-774. https://doi.org/10.1007/s11269-006-9076-5

Wilhite, D. A., \& Vanyarkho, O. V. (2000). Drought: Pervasive impacts of a creeping phenomenon. Retrieved from http://digitalcommons.unl.edu/droughtfacpub/71/

World Food Programme. (2014). Drought: Food security and livelihoods affected by erratic weather. Retrieved from https://www.wfp.org/sites/default/files/LJoint $\% 20$ Assessment\%20of\%20Drought $\% 20$ Impact\%20on\%20Food\%20Security\%20an d\%20Livelihoods_fi....pdf

Zubair, L. (2005). Modernisation of Sri Lanka's Traditional Irrigation Systems and Sustainability. Science Technology \& Society, 10(2), 161-195. https://doi.org/10.1177/097172180501000201 